\section{Research Article}

(c) 2021 Nur Ali et al.

This is an open access article licensed under the Creative Commons Attribution-NonCommercial 4.o International License (https://creativecommons.org/licenses/by-nc/4.o/)

\title{
An Analysis of Psychological Dynamics and Factors Causing the Formation of the Radicalism Attitude Among University Students in Palu
}

\author{
Muhammad Nur Ali ${ }^{1^{*}}$ \\ Rahmat Bakri \\ Muthia Aryuni ${ }^{1}$ \\ Effendy ${ }^{1}$ \\ ${ }^{1}$ Tadulako University, \\ Jl. Soekarno Hatta No.KM. 9, \\ Tondo, Mantikulore, Kota Palu, \\ Sulawesi Tengah 94148, Indonesia \\ ${ }^{*}$ Corresponding Author
}

DOI: https://doi.org/10.36941/jesr-2021-0126

\section{Abstract}

Radicalism is an important issue in Indonesia and it starts penetrating into higher education institutions. Young generation becomes a proper target to spread such radicalism. This present research is aimed at analyzing the radicalism attitude tendency among university students. The instrument employed is the results of the adaptation and modification from the Activism-Radicalism Intention Scale (ARIS) and the University Students' Attitude Tendency. Then, an analysis of the causing factors and the dynamics of such radicalism attitude is also discussed in this present research. It was found that $44.5 \%$ university students tended to have a low radicalism attitude tendency, $5.6 \%$ high, and $11.3 \%$ very high. Their age ranged from 1626 years. Interestingly, the low rate of the radicalism attitude tendency is predicted to be higher, if no preventive action is immediately taken. This prediction is that the results of analysis using Bandura's social cognitive theory namely behavior, environment, and person would greatly contribute to the formation of the radicalism attitude. The contribution of this present research to the literature is made by providing innovative ways to detect the radicalism attitude tendency among university students, the causing factors, and the dynamic of the formation of such attitude.

Keywords: Youth, Radicalism, Dynamics, Attitude, Social Cognitive

\section{Introduction}

Radicalism is a serious problem for the whole world and becomes a real threat to human community at present. Various research results dealing with radicalism show that this case is vital and needs to be quickly handled. Radicalism may be undergone by anyone regardless of his/her religious, educational, tribal, racial backgrounds, and the like. Interestingly, young generation is also involved in radicalism acts such as those that occurred in Hong Kong, where there was a great spike of 
activism and radicalism among university students (Wong et al., 2019). Them some research results also showed that young generation is involved in a radicalism network namely: the occurrence of the increase of the intensity of the radicalism discourse among youth in Aceh in 2017 (Ilyas et al., 2020); the influence of technology and globalization through the online media and a radical narration which may effectively influence and recruit young generation (Suyanto et al., 2019); active radicalism found among the youth in Europe and Sub-Saharan Africa (Norman, 2019); a lot of youths who are not multicultural anymore in the society and who possess a narrow ideology due to the exposure of radicalism (Widyawati \& Albino, 2020).

The phenomenon of radicalism in Indonesia may be more clearly identified. Various headlines in the mass media highlight radicalism events. The reality that Indonesian society is pluralistic with various differences and interest causes Indonesian people to be susceptible to conflicts. Indonesia is known as a country with the highest number of followers of Islam in the world, therefore it always attracts attention to the people all over the world dealing with radicalism and terrorism actions. A study by (Widyaningrum \& Dugis, 2018) in 2011 showed that Indonesia could be included into a country with a high level of radicalism susceptibility with the range of 43.6 , meaning that it is above the safe level threshold of 3.33 .

Some higher education institutions in Indonesia have also been penetrated by radicalism. In 2009, three students of UIN Syarif Hidayatullah were arrested by Densus 88 (an anti-terror unit possessed by the Police of the Republic of Indonesia) with the indictment of terrorism action and they were sentenced 4.5 years in jail in September 2010. Then, in May 1020 the Densus 88 troops also seized two students of University of Muhammadiyah Solo (UMS) with the suspicion of being involved with the deployment of terrorist activities in Aceh. In the same year, the Densus 88 also apprehended an alumnus of Bandung Institute of Technology (ITB) and he was determined as the suspect of a terrorist case. Shocking news came from the Densus 88 that it succeeded in picking up three alumnus of Riau University (Unri) because they were suspected in a terrorism case and they were assembling bombs in their campus in 2018 (Hidayat, 2018).

An economic gap, inequality, and injustice have been used by a group of people believing that the existing system or rules should be replaced in radical changes. The emergence of fundamentalism, radicalism, even terrorism is a reaction to dissatisfaction some people experience with the economic, social, and political conditions in a country. Such urgent conditions are considered as terrible ones, so that these bring up alternative solution thoughts that are expected to be quickly realized through violence without considering its long-term effects.

It is in line with the research result provided by (Sholikin, 2018) that radicalism is a starting point of the emergence of terrorism behavior. Poso regency is the central point of conflict in Central Sulawesi and it is clear that the terrorism habitat has been established in Poso through fundamentalism-radicalism (Ali, 2016). Terrorism behavior emerges due to some factors: ethnicity, differences in faith, socio-economic status, and group's or individual's interest (Whitfield, 2015). Radicalism often embodies extreme, terrorist, and destructive behaviors(Lewis, 2017). Radical actions which end in terrorism actions cause a lot of losses for the surrounding society, such as the emergence of psychological effects in the form of from depression and trauma, food scarcity, prolonged feelings of anxiety and fear to losses of family and relatives. (Ali, 2017). It is known that actually radicalism, extremism, and terrorism are not new problems, but now this phenomenon is worrying enough. A research conducted by the State Intelligence Agency (BIN) showed that around $39 \%$ university students were exposed to radicalism and three high education institutions were found to become the bases for the deployment of radicalism but their identities were not revealed(Akbar, 2018).

Preventing radicalism and terrorism especially in the higher education environment is vital since the university students' ages are susceptible to detrimental influences from outside of the country. University students are at the stage of searching identity where they are often confused with their self-identity, as a result, they are easily affected by the political socialization and interest of certain religions. On the basis of social psychology theory, university students included into the 
young group at the transitional stage is a part of the society that is susceptible to social deprivation. This condition is marked by dissatisfaction, alienation, and frustration so that they are easily influenced by extremism and radicalism values (West, 2013). There are some factors giving positive influences to the formation of anti-radicalism behavior among students namely the mission of the university, the leadership, and the curriculum (Chalim, 2018).

Furthermore, an ideology is also one of the causes of the development of radicalism among university students. Theoretically, students with high intellectual capability level, if they have radical beliefs through intense and long discussion, at last may accept the radicalism(Rafay, 2013). The use of technology through the social media and the virtual network is one of the strategic tools the radical groups employ to widen and strengthen their network. Concerning with the millennial generation at present, they may be included into active users of the social media. Social media may serve as a medium for recruiting and arousing sympathy from individuals who feel unfavorable conditions so that this may trigger the emergence of the feeling of solidarity for instance poverty condition, personal problems, social inequality, and so on (Suraya \& Mulyana, 2020).

Higher education institutions have great influences to the anticipation of radicalism among university students. Moreover, higher education institutions should possess an effective deradicalisation prevention method and approach expected to be able to play a role model for the government and other higher education institutions to prevent and cope with radicalism in the campus environment (Rafay, 2013). It is in the same vein with that stated by the National Counter Terrorism Agency (BNPT) that the government should find a strategy to prevent the spread of radicalism through the strengthening of the curriculum in Higher Education Institutions which are considered as the center for sciences and innovations, so that university students will not be easily deceived by various dogmas and other radicalism. Deradicalisation programs do not only become the responsibility of the BNPT but Higher Education Institutions as well and they may determine the future of Indonesia (Harususilo, 2018).

\section{Literature Review}

\subsection{Radicalism in Higher Education Institutions}

Radicalism means as one's very high belief in a certain value or ideology that may cause one to close any possible truth from other ideologies(Carter, 2018). Meanwhile, (Maskaliūnaitè, 2016) thought that radicalisation is a process where one adopts a belief system that justifies the use of violence to make social changes. Radicalism is an attitude or thought with the following characteristics: 1) being intolerant and disrespect to differences proposed by others; 2) being exclusive namely showing closed attitude and desire to be different from habits shown by common people; 3) being fanatic namely being confident that one is always right, so one blames others; and 4) being revolutionary namely a tendency to make quick changes through violence (Carter, 2018).

Teenagers who fell into radicalism attitude may be caused by factors related to personal conflicts such as social exclusion, feelings of worthlessness, and financial problems they should solve (Sieckelinck et al., 2019). Adolescent development is greatly dependent upon the supporting system around them. Some research results showed that adolescents with environmental conditions such as problematic families and negative parenting(Riany et al., 2019); school situations that do not attend the relationship quality between teachers and students and among students (Andrews, 2014); and a group of adolescents who feel not to be accepted and exiled by their peers (Šiňanská \& Tóthová, 2018) are those with high risks and susceptibility to join in radical movements or groups.

According to (Asrori, 2017), there are three factors causing radicalism in Indonesia, namely the current development at the global level, the spread of Wahhabism and the poverty level. Radicalisation is a process where one moves to support or adopt radical attitudes to reach a certain goal (Carroll, 2015). The process occurs in a number of ways where the most influential one is the role played by the mass media that presents information dealing with radical attitudes to terrorism 
threat (Khairil et al., 2017).

Radicalisation does not immediately happen, but it should pass some long processes. (Wiktorowicz, 2005) explains five radicalisation stages of an individual, namely: 1)the first stage is called cognitive opening, a stage where an individual will open himself and his mind to sciences, ideas, and new experiences considered to be right so that he will leave his old point of view that has been acquired, 2) the second stage is religious seeking, where at this level an individual starts searching for religious meanings shown by actively joining in various types of religious activities such as lectures and discussions either an open or closed way. At this stage, members of a radical group with high credibility will more easily influence an individual who seems susceptible to radicalism. 3) The third stage is framing. At this stage, a preacher or a person with a high rank in the radical group begins giving propaganda or lecturing to attract the individual which seems susceptible to join in their groups. Various persuasive and agitative techniques accompanied with religious postulates are made use of to make sure the prospective group member; 4) The fourth stage is sozialisation, where at this stage the individual starts getting religious instructions facilitating indoctrination, building an exclusive identity and making changes of belief values, and 5) the last stage is internalization where at this state, the individual begins to understand and deepen the most correct ideology. After passing through the five stages, an individual will join in the radical group and is ready to make certain actions instructed by the leader in the group.

\subsection{Radicalism in the Psychological Perspective}

The persons joining in a radicalism group are included into minority groups. The question is as follows: is it possible for the minority groups to be able to influence the majority group? The answer is that it might happen. (Cvetkovska et al., 2020) explained that minority groups may influence the majority group if two conditions exist namely: 1) there is a problem concerning with public interest, they may become the front line, and 2) they can be trusted and consistent with their struggle and ideology.

Terrorism is the results of a radicalization process starting from an individual to group levels. Radicalism is a social movement that is extremely carried out and this includes four significant aspects: being intolerant, fanatic, exclusive and anarchistic with the aim at creating drastic changes. A community with radicalism usually has a leader considered to possess an authoritative figure indoctrinating his members so that their mindset will change and they are willing to do what is instructed consciously. The behavior shown on the basis of a desire to fulfill others' requests or the behavior occurring as the result of a direct response to a request from others is called obedience (Grzyb et al., 2018). Obedience is included into one of the social behaviors where an individual will obey and follow others' request to do something due to an authority element (Meyer, 2021). The existence of an authoritative figure in a group makes its members willing to do anything instructed without thinking of the consequences. There are five elements affecting the emergence of such obedience behaviors, namely trust and loyalty to the leader, the authoritative figure becoming the leader of the group, the regulation in the group and the implementation of the regulations themselves (Haslam et al., 2016).

Furthermore, a radical group possesses a strong belief in the truth of the order or ideology they adhere to. The belief in the change of the order is often under the name of human values as the justification that the belief is a part of a social movement. Such a strong belief may raise certain attitudes, even justify violence. An attitude means an individual's reaction or response to a stimulus which then brings out an attitude towards something or an object in certain ways. (Jin et al., 2020). In general, an attitude consists of three components namely cognitive, affective and conative (behavioral tendencies). Information is received by an individual through the process of assimilation, synthesis, and evaluation, then it results in new values which later will be accommodated or assimilated with previously existing knowledge in the individual's brain (Algara \& Hale, 2020). The process produces an evaluation of something that is believed to be good, right, bad, wrong, and the 
like (Sude et al., 2021). An evaluation of an object affects emotions or affective components from the individual's attitude manifested in the form of behavior (Min et al., 2020). Basically, radicalization is a response to a phenomenon that is occurring, where the resulted response may vary such as criticism or refusal to a policy or a rule that may end in resistance.

\subsection{A Study of Social Cognitive Theories and the Formation of Radicalism Attitude}

The social cognitive theory proposed by Bandura emphasizes the fact that all information an individual obtains is from his interactions with others (Bandura, 2012). Humans as social creatures process information through direct or indirect learning in a social setting accompanied by resulted consequences. The main concept of the social cognitive theory is the formation of attitude obtained from the results of observations known as observational learning (Borsa et al., 2019). Observational learning means a process of one's attitude formation by observing and learning something around him through four stages: attention, retention, production and motivation.

The social cognitive theory has been used to explain the formation of attitude and behavior in human beings. Humans' cognitive, affective and behavioral changes are formed through the process of observing others. Bandura explained that there are three main factors contributing to the formation of human behavior namely behavior, environment and person. This model is known as reciprocal determinism. The three factors interact and influence one another in the learning process. This reciprocal determinism model may also explain the process of the emergence of the radicalism attitude among university students. Starting from university students' participation in non formal discussion forums talking about the ideology of radicalism, then it makes them choose an environment including friends who are relatively the same with theirs, either in terms of thoughts or understanding. Moreover, the group also possesses a high solidarity so that this forms the feelings of interest and comfort and of being accepted in the group. These feelings make an individual have colleagues with the same condition, so that he will devote all of his life to defend and maintain his group, including conducting violent actions.

Individuals who are always being indoctrinated dealing with radical attitudes without any explanation of respecting differences, tolerance, openness and solution to any dissent will at last internalize the values in themselves, so that the values will become a sedentary character. Individuals become more closed and are unwilling to accept differences and tend to use a constructive approach to solving problems so that the radicalism actions are considered to be right and valid to do especially to reinforce something considered to be right (Karell \& Freedman, 2019). An individual succeeding in carrying out a radical action will be regarded to be great by his group and he may get a certain recognition even reward. Such an action may trigger or exemplify others in the group to do the same thing.

The event is properly explained using Bandura's social cognitive theory that social and cognitive factors play vital roles in learning. The cognitive factor is one's expectation to reach the success and the social factor includes one's observation of others' behavior. The cognitive development including the standard of performance and moral evaluations always changes on the basis of the results of observations and interactions with others. Bandura identified learning by making others' behavior and any consequences received as a model that may be imitated. This process is known with the term observational learning (Bandura, 2016).

\section{Methodology}

\subsection{Sampling}

The population of this present research was active university students in five higher education institutions in Palu city, Central Sulawesi province, Indonesia. A purposive sampling technique in line with the characteristics of each high education institution was adopted. The number of the 
sample was 309 university students with the following characteristics:

\subsubsection{Respondents based on age}

The respondents' identities on the basis of age were informed through the following frequency and explanation (Table 1).

Table 1: Respondents based on age

\begin{tabular}{|c|c|c|}
\hline Age & Frequency & Percentage \\
\hline $16-20$ Years & 181 & $58.6 \%$ \\
\hline $21-25$ Years & 125 & $40.5 \%$ \\
\hline $26-30$ Years & 3 & $0.6 \%$ \\
\hline Total & $\mathbf{3 0 9}$ & $\mathbf{1 0 0} \%$ \\
\hline
\end{tabular}

Based on the table above, it is known that from 309 university students involved in this research, $58.6 \%$ respondents were from 16 years to 20 years old, $40.5 \%$ respondents were from 21 years to 25 years old, then $0.6 \%$ respondents were from 26 years old to 30 years old and $0.3 \%$ respondents were 30 years old or higher. This shows that the age of most university students involved in this research ranges from 16 years to 30 years.

\subsubsection{Respondents based on sex}

The respondents' identities based on sex are presented through the frequency distribution and the following explanation (Table 2):

Table 2: Respondents based on sex

\begin{tabular}{|c|c|c|}
\hline Types of Sex & Frequency & Percentage \\
\hline Male & 139 & $45.0 \%$ \\
\hline Female & 170 & $55.0 \%$ \\
\hline Total & $\mathbf{3 0 9}$ & $\mathbf{1 0 0} \%$ \\
\hline
\end{tabular}

On the basis of the table above, it is revealed that from 309 university students involved in this research, $45.0 \%$ respondents were male, and $55.0 \%$ respondents were female. This shows that most university students involved in this research were female.

\subsubsection{Respondents based on the semester level}

The respondent's identities on the basis of the semester level is represented in the frequency distribution and the explanation as follows (Table 3 ).

Table 3: Identity of respondents based on the semester level

\begin{tabular}{|c|c|c|}
\hline Semester & Frequency & Percentage \\
\hline Semester 1 - 2 & 25 & $8.1 \%$ \\
\hline Semester 3-4 & 93 & $30.1 \%$ \\
\hline Semester 5 - 6 & 119 & $38.5 \%$ \\
\hline Semester 7 - 8 & 58 & $18.8 \%$ \\
\hline > Semester 8 & 14 & $4.5 \%$ \\
\hline Total & $\mathbf{3 0 9}$ & $\mathbf{1 0 0} \%$ \\
\hline
\end{tabular}


On the basis of the table above, it is known that from 309 university students involved in this present research, $8.1 \%$ respondents were on semester 1 to 2 , 30.1\% respondents on semester 3 to 4 , then $38.5 \%$ respondents on semester 5 to $6,18.5 \%$ on semester 7 to 8 , and $4.5 \%$ respondents were on semester 8 or higher. This suggests that most university students involved in this research wereon semester 5 to 6 .

\subsection{Measurement}

The instrument employed in this research was the results of adaptation and modification from Activism and Radicalism Intention Scales (ARIS) (Moskalenko \& McCauley, 2009) and the University Students' Attitudes Tendency the researchers constructed. The total number of statements in the scale used was 40 items. The following is the complete explanation of the two instruments.

\subsubsection{Activism and Radicalism Intention Scales (ARIS)}

ARIS contains an explanation that activism easily leads to radicalism. Most radical attitudes come from activism. The ARIS scale reveals how an individual possesses an attitude tendency and belief in political actions, violence and terrorism. This scale consists of 18 statement items using a Likert scale.

\subsubsection{University Students' Attitudes Tendency (USAT)}

USAT is a combination of four indicators of the radical attitude tendency namely: being intolerant, fanatic, exclusive, and anarchistic. Each indicator consists of 10 statement items divided into 5 items: favorable and 5 items: unfavorable, using a Likert scale.

\subsection{Analytical methods}

The scale employed as the tool for the data collection was tried out first. The tryout is intended to test its validity and reliability. Namely, it is aimed at measuring the levels of accuracy and reliability of the questionnaires as the tool for the data collection. The testing of this instrument validity was carried out using the Point Biserial technique, where the testing criteria using the Point Biserial technique say that if the correlation coefficient $\left(\mathrm{r}_{\mathrm{iT}}\right) \geq$ the Table correlation $\left(\mathrm{r}_{\text {tabel }}\right)$, it means that the questionnaire items are valid or are able to measure the variable they should measure, then they could be used as the tool for the data collection. On the basis of the results of testing the variable validity, it was revealed that all items possessed the correlation coefficient value with the total scores $\mathrm{r}_{\mathrm{iT}}$ ) > Table correlation value (o.195). Therefore, the questionnaire items in the radicalism attitude tendency variable are stated to be valid.

Then, the testing of the instrument reliability is intended to understand the validity and consistency of the research instrument as the tool for measuring the variables measured. A Split-Half technique was used to test the reliability. The testing criteria say that if Spilt-Half coefficient $\geq 0.6$, it means that the questionnaire items are stated to be reliable or consistent to measure the variables measured. On the basis of the results of the testing the reliability of this research instrument, it is revealed that the Radicalism Attitudes Tendency variable results in the Spilt-Half coefficient value > o.6. Therefore, the questionnaire/statement items in the variable are declared to be reliable or consistent, and then they could be used as the tool for the data collection in this research. For the data analysis, a statistical package of SPSS 22.0, namely the crosstab descriptive statistical analysis (including the mean and the correlation) was employed. The crosstab descriptive analysis presents data in the form of tabulation covering rows and columns.

\section{Results}

It was found that from 309 university students in this research, 58.6\% respondents were at the age 
from 16 years to 20 years, $40.5 \%$ respondents, from 21 years to 25 years, then $0.6 \%$ respondents, from 26 years to 30 years and $0.3 \%$ respondents were at the age of 30 years or higher. This shows that the age of most university students involved in this research ranged from 16 years to 30 years.

Then it was revealed that from 309 university students involved in this research, $45.0 \%$ respondent were male, and $55.0 \%$ respondent were female. This suggests that most university students involved in this research were female.

The descriptive analysis of the Radicalism Attitudes Tendency variable is presented in the following Table 4:

Table 4: A Descriptive Analysis of the Radicalism Attitudes Tendency Variable

\begin{tabular}{|c|c|c|c|l|}
\hline No & Score Range & Frequency & Percentage & \multicolumn{1}{|c|}{ Category } \\
\hline 1 & $40.0<\mathrm{X} \leq 75.0$ & 0 & $0.0 \%$ & Very Low \\
\hline 2 & $70.0<\mathrm{X} \leq 100.0$ & 275 & $44.5 \%$ & Low \\
\hline 3 & $100.0<\mathrm{X} \leq 130.0$ & 34 & $5.5 \%$ & High \\
\hline 4 & $130.0<\mathrm{X} \leq 160.0$ & 0 & $0.0 \%$ & Very High \\
\cline { 1 - 4 } Total & 309 & $\mathbf{5 0 . 0} \%$ & \\
\cline { 1 - 2 } Mean & & & Low \\
\hline \multicolumn{2}{|l|}{ Category } & & & 92.88 \\
\hline
\end{tabular}

From the table above, it is shown that the mean of the university students' radicalism attitude tendency was 92.88. It means that the university students' radicalism attitude tendencies were classified under the low category. The university students' radicalism attitude tendency in the low category was at the interval of $40.0<\mathrm{X} \leq 75.0$ with o $(0.0 \%)$ respondent. Then university students' radicalism attitude tendency in the low category was at the interval of $70.0<\mathrm{X} \leq 100.0$ with 275 (44.5\%) respondents. The next is the university students' radicalism attitude tendency in the high category was at the interval of $100.0<\mathrm{X} \leq 130.0$ with $34(5.5 \%)$ respondents. While the university students' radicalism attitude tendency in the very high category was at the interval of $130.0<\mathrm{X} \leq$ 160.0 with o $(0.0 \%)$ respondent

\subsection{The cross tabulation analysis between the age and the radicalism attitude tendency}

The cross tabulation of the age with the radicalism attitude tendency may be identified from the following Table 5 .

Table 5: A cross tabulation analysis of age and radicalism attitude tendency

\begin{tabular}{|c|c|c|c|c|c|c|}
\hline \multirow{3}{*}{ Age } & \multicolumn{4}{|c|}{ Radicalism } & \multirow{2}{*}{\multicolumn{2}{|c|}{ Total }} \\
\hline & \multicolumn{2}{|c|}{ Low } & \multicolumn{2}{|c|}{ High } & & \\
\hline & $\mathbf{n}$ & $\%$ & $\mathbf{n}$ & $\%$ & $\mathbf{N}$ & $\%$ \\
\hline $16-20$ Years & 164 & $53.10 \%$ & 17 & $5.50 \%$ & 181 & $58.60 \%$ \\
\hline $21-25$ Years & 108 & $35.00 \%$ & 17 & $5.50 \%$ & 125 & $40.50 \%$ \\
\hline $26-30$ Years & 2 & $0.60 \%$ & $\mathrm{o}$ & $0.00 \%$ & 2 & $0.60 \%$ \\
\hline
\end{tabular}

The results of the calculation show that from 309 university students involved in this research, $53.10 \%$ respondents at the age of from 16 years to 20 years had a low radicalism attitude tendency, 5.50\% respondent at the age of from 16 years to 20 years possessed a high radicalism attitude tendency

Then $35.00 \%$ respondents at the age of from 21 years to 25 years revealed a low radicalism attitude tendency, and $5.50 \%$ respondents at the age of from 21 years to 25 years owned a high radicalism attitude tendency.

Further, $0.60 \%$ respondents at the age of from 26 years to 30 years had a low radicalism attitude 
tendency.

\subsection{A Cross Tabulation Analysis of Semester and Radicalism Attitude Tendency}

A cross tabulation between semester and the radicalism attitude tendency is presented in the following Table 6:

Table 6: A Cross Tabulation Analysis of Semester and Radicalism Attitude Tendency

\begin{tabular}{|c|c|c|c|c|c|c|}
\hline \multirow{3}{*}{ Semester } & \multicolumn{4}{|c|}{ Radicalism } & \multirow{2}{*}{\multicolumn{2}{|c|}{ Total }} \\
\hline & \multicolumn{2}{|c|}{ Low } & \multicolumn{2}{|c|}{ High } & & \\
\hline & $\mathbf{n}$ & $\%$ & $\mathbf{n}$ & $\%$ & $\mathbf{n}$ & $\%$ \\
\hline Semester $1-2$ & 23 & $7.40 \%$ & 2 & $0.60 \%$ & 25 & $8.10 \%$ \\
\hline Semester $3-4$ & 87 & $28.20 \%$ & 6 & $1.90 \%$ & 93 & $30.10 \%$ \\
\hline Semester $5-6$ & 101 & $32.70 \%$ & 18 & $5.80 \%$ & 119 & $38.50 \%$ \\
\hline Semester $7-8$ & 52 & $16.80 \%$ & 6 & $1.90 \%$ & 58 & $18.80 \%$ \\
\hline$>$ Semester 8 & 12 & $3.90 \%$ & 2 & $0.60 \%$ & 14 & $14.50 \%$ \\
\hline
\end{tabular}

The results of the calculation showed that from 309 university students involved in this research, $7.40 \%$ respondents at the semester 1 to 2 had a low radicalism attitude tendency and $0.60 \%$ respondents at semester 1 to 2 owned a high radicalism attitude tendency

Then, $28.20 \%$ respondents at 3 to 4 suggested a low radicalism attitude tendency and $1.90 \%$ respondents at semester 3 to 4 showed a high radicalism attitude tendency.

Moreover, $32.70 \%$ respondents at semester 5 to 6 revealed a low radicalism attitude tendency and $5.80 \%$ respondents at semester 5 to 6 possessed a high radicalism attitude tendency.

The next is that $16.80 \%$ respondents at semester 7 to 8 showed a low radicalism attitude tendency. and $1.90 \%$ respondents at semester 7 to 8 had a high radicalism attitude tendency.

While $3.90 \%$ respondent at semester 8 or higher showed a low radicalism attitude tendency, and $0.60 \%$ respondent at semester 8 or higher had a high radicalism attitude tendency.

\section{Discussion}

At present the millennial or young generation is the main target to spread radicalism through the information technology. The psychological condition that still tends to be unstable and minimum knowledge of radical attitude makes them be easily influenced by such radicalism. Moreover, the lack of critical thinking ability in the given information also result in them to be easily indoctrinated continually.

On the basis of the data analysis, it is found that $275(44,5 \%)$ respondents show a low radicalism attitude tendency $(70,0<\mathrm{X} \leq 100.0)$, and $34(5,5 \%)$ respondents have a high radicalism attitude tendency $(100.0<\mathrm{X} \leq 130.0)$. From the results of the analysis, the number of respondents with a low radicalism attitude tendency higher than that of high one. However, on the basis of the research results (Kruglanski, 2018) that the main cause of radical actions and terrorism are not from the psycho-pathology factors, and they are much influenced by the environmental factors or the social learning results obtained from the factors of kinship, solidarity, friends' persuasion, instruction form a person considered to be senior..

Inexistent pathological elements in individuals in a radical group do not mean that psychological factors do not contribute to the emergence of radical attitude. A research result by (Borum, 2011) showed that individuals involved in radical groups or organizations and terrorism do not show any psycho-pathological indications or have certain types of personality, but the manifestation of the behavior is oriented into actions leading them to behave aggressively. Individuals' involvement in an action or behavior considered to be in opposition to the prevailing 
norms and values adhered by most people is categorized into criminal behavior, since radicalism and terrorism usually result in victims. (Snow \& Cross, 2011).

Life experience or parenting is often considered as the factor that plays a vital role in forming individual behavior. There are factors causing the radicalists and fundamentalists to be easily caught into becoming terrorists: disharmonious family condition (Carter, 2018), poor economic condition (Schmid, 2013), social unacceptability from the people (Karell \& Freedman, 2019), failure in social interactions with groups and failures in job or education (Bötticher, 2017). The accumulation of failure, uncomfortable even anxious feelings at last become the trigger for an individual to show behavior which is not in line with the prevailing values or rules (Kim, 2016).

The findings from some research results suggest three important matters presumed to cause the emergent radicalism attitudes among university students namely: cognitive biases in perceiving an information, the phenomenon of socio-political conditions either in Indonesia or the world, inexistent role models that may serve as models that at last be reinforced by the psychological condition of each individual.

It can be concluded that the formation of radicalism attitude is triggered by three main factors: individual, group, and situation. Factors existing in an individual plays a great role in forming thoughts and tendencies of individual behavior. The status of the relationship of an individual in a group will also create self-efficacy, namely, a strong belief that the most effective way to reach an ideological goal is by doing acts of violence. The belief will strengthen radical thoughts and raise acts of violence.

Each individual possesses personal problems. It must also happen to university students. The findings of this present research showed that $11.3 \%$ university student at the age of from 16 years to 26 years had a high tendency to possess radicalism attitudes. But these data may change, depending on the surrounding environmental or psychological conditions of each individual. Viewed from previous events, most people committing suicide bombing were young generation.

From the age, university students are under the late teenagers category where they are experiencing a storm and stress phase (Garrigan et al., 2018) resulted by a transition period from childhood to adulthood. They begin to be confused and to doubt their identities (the search for identity phase) Various pressures concerning with the transition period cause the emergence of a lot of varieties of psychological problems such as identity crisis and anxiety (Shields et al., 2021), low selfesteem and insecure that may cause stress even depression (Bussemakers \& Kraaykamp, 2020). Such conditions become one of the heavy phases in the development human life. One of the ways done by the youth to solve such problems is by building togetherness in groups that may make them feel better because they don't feel alone. Becoming a member of a group is an effort made by an individual to save himself from the identity crisis he experiences. However, in order to be able to be accepted in a group, an individual should behave in a conformity way, namely adjusting himself to the group by following the norms and values that are adhered by the group.

Technology plays a vital role in succeeding in the spread of radicalism. One of the sources of the emergence of radicalism is the use of the Internet media by an organization to recruit members and sympathizers in an easy, massive, cheap and relatively quick way. (Kleemola, 2019). At present, it seems that many media users in the online network are dominated by the youth or the millennial generation who then become an easy target to spread doctrines without direct face to face interactions. Indoctrination is carried out by making webs in certain sites or channels in the Youtube by showing radicalism, spreading hateful ideas to other groups that are not at the same belief or school, even making a video on assembling bombs which is considered as one of the tools to struggle truth (Arifianto, 2019).

Individuals who are often interacted with one group with radicalism, either directly or indirectly through the cyberspace may potentially be easy to join in radicalism and to motivate to carry out radical actions (Alam, 2020). An environment gives a greatly strong influence to the formation of an individual's behavior. As explained in the Bandura's social cognitive theory (Proctor \& Niemeyer, 2020) that the formation of behavior is influenced by three factors namely: environment (E), person $(P)$, behavior $(B)$. The environment around an individual potentially gives a stimulus in the form of 
information, then it is cognitively processed which at last raises a behavior. If the environment gives a positive response to the emergence of the behavior, then it will play its role as a stimulus in an environment then this affects the individual and his behavior. The interaction among the three factors is known as triadic reciprocal determinism.

In this case, an environment plays a vital role in forming radicalism. An environment is like a group or community adhering radicalism. Then, the acceptance and support to actions made by individuals in the group, if the actions are in line with what are expected by the group, at the end make the individual feel to be accepted in the group. The acceptance and support given by the group is a positive consequence received by the individual as an effort made in order that his existence in the group can be recognized.

Therefore, it is very vital to know earlier the tendency of radical attitudes occurring to university students. The data may be used as a basis to give further intervention concerning with the prevention of high radicalism attitude among university students. Because on the basis of some research results above, the radicalism attitude may be learned from the surrounding environment. The facts show that radicalism is really found in daily life. It starts from an individual's radical mindset, then radical groups with high solidarity are established, and protest actions ending with violence are made. Anarchistic actions with violence may raise the feeling of restless and terror in the society that may make them feel restless and threatened.

Radicalism is like a time bomb that may blow out immediately, since it keeps a great danger. Moreover, radicalism may also destroy young generation's thoughts and mind because radicalism often stands as an ideology in opposition with that of the government. It is not necessary to obey rules, norms, or values that have been determined by the government, even they should be destroyed and then replaced with a government system which is in accordance with the ideology of their group.

\section{Conclusion}

The emergence of radicalism especially among young generation becomes an issue of concern in Indonesia over the few years. Some extremely radical cases occurring in Indonesia have also involved the young generation. The significant development of science and technology changes the world order a lot and gives impacts on the development of radicalism. After being examined and analyzed, there are many factors causing the emergence of radicalism among the young generation, especially university students. Principally, some factors contributing to the emergence of radicalism are as follows: 1) individuals' psychological conditions such as: identity crises, conflicts with others. low selfesteem, anxiety, insecurity, feelings of not being accepted in social groups that may cause stress, 2) environmental factors namely the learning results obtained from social interaction, and 3) behavior supported by positive consequences in the for of recognition and acceptance in a group. The three factors interact and influence one another in the learning process. According to Bandura, the learning process by making others' behavior and the consequence one should receive as a model that may be imitated is the definition of the observational learning used to explain the dynamics of the formation of radicalism among university students. A radicalism attitude tendency which at the beginning is low can increase if there is support from the surrounding environment. Otherwise, the tendency will be lower if they are not given a proper response from the environment.

\section{References}

Akbar, W. (2018). BIN Ungkap 39 Persen Mahasiswa Terpapar Radikalisme. CNN Indonesia, 1-2.

Alam, M. (2020). Reconstructing anti-capitalism as heterodoxa in Indonesia's youth-led urban environmentalism Twitter account. Geoforum, 114(June), 151-158. https://doi.org/10.1016/j.geoforum.2020.06.005

Algara, C., \& Hale, I. (2020). Racial attitudes \&amp; political cross-pressures in nationalized elections: The case of the Republican coalition in the Trump era. Electoral Studies, 68(June), 102207. https://doi.org/10.1016/j.electstud.2020.102207 
Ali, M. N. (2016). Studi Terorisme di Sulawesi Tengah. Al-Ulum, 16(2), 496-516.

Ali, M. N. (2017). The Study of Conflict Victim Aggression at Poso Conflict Region. 163(Icodag), 301-306.

Andrews, K. (2014). Toward a Black Radical independent education: Black radicalism, independence and the supplementary school movement. Journal of Negro Education, 83(1), 5-14. https://doi.org/10.7709/jnegroeducation.83.1.0005

Arifianto, A. R. (2019). Islamic Campus Preaching Organizations in Indonesia: Promoters of Moderation or Radicalism? Asian Security, 15(3), 323-342. https://doi.org/10.1080/14799855.2018.1461086

Asrori, A. (2017). Radikalisme di Indonesia: Antara Historisitas dan Antropisitas. Kalam, 9(2), 253. https://doi.org/10.24042/klm.vgi2.331

Bandura, A. (2012). Social cognitive theory. In Handbook of Theories of Social Psychology: Volume 1 (pp. 349-374). https://doi.org/10.4135/9781446249215.n18

Bandura, A. (2016). The power of observational learning through social modeling. In Scientists Making a Difference: One Hundred Eminent Behavioral and Brain Scientists Talk about their Most Important Contributions (pp. 235-239). https://doi.org/10.1017/CBO9781316422250.052

Borsa, D., Heess, N., Piot, B., Liu, S., Hasenclever, L., Munos, R., \& Pietquin, O. (2019). Observational Learning by Reinforcement Learning. Proceedings of the International Joint Conference on Autonomous Agents and Multiagent Systems, AAMAS, 2, 1117-1124.

Borum, R. (2011). Radicalization into Violent Extremism I. Journal of Strategic Security.

Bötticher, A. (2017). Towards academic consensus definitions of radicalism and extremism. Perspectives on Terrorism.

Bussemakers, C., \& Kraaykamp, G. (2020). Youth adversity, parental resources and educational attainment: Contrasting a resilience and a reproduction perspective. Research in Social Stratification and Mobility, 67(April), 100505. https://doi.org/10.1016/j.rssm.2020.100505

Carroll, W. K. (2015). What " Radical " Means in the 21st Century. Review of Radical Political Economics, 47(4), 663-668. https://doi.org/10.1177/0486613415574272

Carter, E. (2018). Right-wing extremism/radicalism: Reconstructing the concept. Journal of Political Ideologies, 23(2), 157-182. https://doi.org/10.108o/13569317.2018.1451227

Chalim, S. (2018). Pengaruh Misi, Kurikulum dan Kepemimpinan di Perguruan Tinggi Terhadap Perilaku AntiRadikalisme Mahasiswa. Jurnal Pendidikan Dan Kebudayaan, 3(2013), 33-43. https://doi.org/10.24832/jpnk.v3i1.728

Cvetkovska, S., Verkuyten, M., \& Adelman, L. (2020). Being tolerated and minority well-being: The role of group identifications. International Journal of Intercultural Relations, 74(October 2019), 161-173. https://doi.org/10.1016/j.ijintrel.2019.10.010

Garrigan, B., Adlam, A. L. R., \& Langdon, P. E. (2018). Moral decision-making and moral development: Toward an integrative framework. In Developmental Review. https://doi.org/10.1016/j.dr.2018.06.001

Grzyb, T., Doliński, D., Trojanowski, J., \& Bar-Tal, Y. (2018). Cognitive structuring and obedience toward authority. Personality and Individual Differences, 133(December 2016), 115-120. https://doi.org/10.1016/j.paid.2017.08.032

Harususilo, Y. E. (2018). Lawan Terorisme, BNPT Berikan Pembekalan Mahasiswa Baru ITS Halaman all—Kompas. Kompas.Com.

Haslam, S. A., Reicher, S. D., \& Birney, M. E. (2016). Questioning authority: New perspectives on Milgram's "obedience" research and its implications for intergroup relations. Current Opinion in Psychology, 11, 6-9. https://doi.org/10.1016/j.copsyc.2016.03.007

Hidayat, M. (2018). Bibit Terorisme di Kampus-Kolom Tempo. Majalah Tempo.

Ilyas, M., Ismail, Z., Abdullah, M. A., \& Zulfidar, F. (2020). Youth Existence and Radicalism in Aceh, Indonesia. Jurnal Ilmiah Peuradeun. https://doi.org/10.26811/peuradeun.v8i2.431

Jin, X., Shi, Y., Tang, Y., \& Wu, X. (2020). Event-triggered attitude consensus with absolute and relative attitude measurements. Automatica, 122, 109245. https://doi.org/10.1016/j.automatica.2020.109245

Karell, D., \& Freedman, M. (2019). Rhetorics of Radicalism. American Sociological Review, 84(4), 726-753. https://doi.org/10.1177/ooo3122419859519

Khairil, M., Ali, M. N., Zakaria, S. Z. S., Arifin, K., \& Razman, M. R. (2017). Mass media coverage on terrorism in order to achieve peace and justice according to the World Agenda of Sustainable Development Goals (SDGs). Information (Japan), 20(7), 4935-4940.

Kim, D. S. (2016). The rise of European right radicalism: The case of Jobbik. Communist and Post-Communist Studies. https://doi.org/10.1016/j.postcomstud.2016.08.001

Kleemola, O. (2019). The visual Narrative of Student Radicalism in Finland: The 1968 occupation of the Old Student House in the Finnish media. Media History, 8804. https://doi.org/10.1080/13688804.2019.1702007 
Kruglanski, A. W. (2018). Violent Radicalism and the Psychology of Prepossession. Social Psychological Bulletin. https://doi.org/10.32872/spb.v13i4.27449

Lewis, G. W. (2017). Radicalism, Counter-Radicalism and the American Legion, 1919-1940. Radical Americas. https://doi.org/10.14324/111.444.ra.2016.v1.1.011

Maskaliūnaitė, A. (2016). Exploring the Theories of Radicalization. International Studies. Interdisciplinary Political and Cultural Journal, 17(1), 9-26. https://doi.org/10.1515/ipcj-2015-00o2

Meyer, M. (2021). Putting the onus on authority: A review of obedient behavior and why we should move on. New Ideas in Psychology, 6o(October 2019), 100831. https://doi.org/10.1016/j.newideapsych.2020.100831

Min, H. (Kelly), Park, J., \& Hu, Y. (2020). Toward understanding the attitude measurements in hospitality research. International Journal of Hospitality Management, 89 (April), 102567. https://doi.org/10.1016/j.ijhm.2020.102567

Moskalenko, S., \& McCauley, C. (2009). Measuring political mobilization: The distinction between activism and radicalism. Terrorism and Political Violence, 21(2), 239-26o. https://doi.org/10.1080/09546550902765508

Norman, I. (2019). Assessment of De-Radicalization Hypothesis in Sub-Saharan Africa. Theory in Action, 12(3), 2148. https://doi.org/10.3798/tia.1937-0237.1920

Proctor, K. R., \& Niemeyer, R. E. (2020). Retrofitting social learning theory with contemporary understandings of learning and memory derived from cognitive psychology and neuroscience. Journal of Criminal Justice, 66(October 2019), 101655. https://doi.org/10.1016/j.jcrimjus.2019.101655

Rafay, A. (2013). An "Impossible Profession"? The Radical University in Prison. The Radical Teacher, 95, 10-21. https://doi.org/10.5406/radicalteacher.95.0010

Riany, Y. E., Haslam, D., Musyafak, N., Farida, J., Ma'arif, S., \& Sanders, M. (2019). Understanding the role of parenting in developing radical beliefs: Lessons learned from Indonesia. Security Journal, 32(3), 236-263. https://doi.org/10.1057/s41284-018-00162-6

Schmid, A. (2013). Radicalisation, De-Radicalisation, Counter-Radicalisation: A Conceptual Discussion and Literature Review. Terrorism and Counter-Terrorism Studies. https://doi.org/10.19165/2013.1.02

Shields, A. N., Giljen, M., España, R. A., \& Tackett, J. L. (2021). The p factor and dimensional structural models of youth personality pathology and psychopathology. Current Opinion in Psychology, 37, $21-25$. https://doi.org/10.1016/j.copsyc.2020.06.005

Sholikin, A. (2018). Potret Sikap Radikalisme Menuju Pada Perilaku Terorisme Di Kabupaten Lamongan. Journal of Governance, 3(2), 184-202. https://doi.org/10.31506/jog.v3i2.3255

Sieckelinck, S., Sikkens, E., San, M. Van, Kotnis, S., \& De Winter, M. (2019). Transitional journeys into and out of extremism. A biographical approach. Studies in Conflict and Terrorism, 42(7), 662-682. https://doi.org/10.1080/1057610X.2017.1407075

Šiňanská, K., \& Tóthová, L. (2018). Radicalization and Extremism as Adolescent Risky Behaviours. Journal of Interdisciplanary Research, 8(2), 239-245.

Snow, D., \& Cross, R. (2011). Radicalism within the Context of Social Movements: Processes and Types. Journal of Strategic Security. https://doi.org/10.5038/1944-0472.4.4.5

Sude, D. J., Pearson, G. D. H., \& Knobloch-Westerwick, S. (2021). Self-expression just a click away source interactivity impacts on confirmation bias and political attitudes. Computers in Human Behavior, 114(May 2020), 106571. https://doi.org/10.1016/j.chb.2020.106571

Suraya, \& Mulyana, A. (2020). Radicalism on teens as the effect of digital media usage. Jurnal Komunikasi: Malaysian Journal of Communication. https://doi.org/10.17576/JKMJC-2020-3601-05

Suyanto, B., Sirry, M., \& Sugihartati, R. (2019). Pseudo-Radicalism and the De-Radicalization of Educated Youth in Indonesia. Studies in Conflict and Terrorism. https://doi.org/10.1080/1057610X.2019.1654726

West, C. (2013). American radicalism. In A Critical Sense: Interviews with Intellectuals (pp. 127-142). https://doi.org/10.4324/9780203754238-12

Whitfield, S. J. (2015). A Radical in Academe. Journal for the Study of Radicalism, 9(2), 93-124.

Widyaningrum, A. Y., \& Dugis, N. S. (2018). Terorisme Radikalisme dan Identitas Keindonesiaan. Jurnal Studi Komunikasi (Indonesian Journal of Communications Studies), 2(1), 32-67. https://doi.org/10.25139/jsk.v2i1.368

Widyawati, F., \& Albino, Y. (2020). Youth Muticultural Community Base on Local Culture of Manggarai as the Effort to Fight Against Violence, Radicalism and Terorism. Jurnal Pendidikan Dan Kebudayaan Missio, 12(1), 20-31. https://doi.org/10.36928/jpkm.v12i1.164

Wiktorowicz, Q. (2005). Wiktorowicz-A genealogy of radical islam.pdf. Studies in Conflict and Terrorism, 28(2), 75-97. https://doi.org/10.108o/10576100590905057

Wong, M. Y. H., Khiatani, P. V., \& Chui, W. H. (2019). Understanding youth activism and radicalism: Chinese values and socialization. Social Science Journal, 56(2), 255-267. https://doi.org/10.1016/j.soscij.2018.08.oo6 